\title{
Fat tissue is not a reservoir for radiocesium in wild boars
}

\author{
Georg Steinhauser ${ }^{1}$ - Christian Knecht ${ }^{2} \cdot$ Wolfgang Sipos $^{2}$
}

Received: 16 March 2017/Published online: 25 April 2017

(C) Akadémiai Kiadó, Budapest, Hungary 2017

\begin{abstract}
Meat of wild boars is not only known for high ${ }^{137} \mathrm{Cs}$ activity concentrations but also for the remarkable constancy of these levels. Even decades after the Chernobyl accident, the ${ }^{137} \mathrm{Cs}$ levels in wild boar meat in Central Europe have not declined but even partly increased. In the present study, we investigated an unusual hypothesis for this very unusual phenomenon: may the boars' fat tissue act as a reservoir for radiocesium? We investigated fat and muscle tissues of four wild boars in Western Germany and found that the ${ }^{137} \mathrm{Cs}$ concentrations in fat were in the range of $10-30 \%$ of the respective activities in muscle tissue. Hence, the hypothesis was refuted.
\end{abstract}

Keywords Wild boar (Sus scrofa) $\cdot{ }^{137} \mathrm{Cs} \cdot$ Fat tissue Muscle tissue $\cdot$ Central nervous system $\cdot$ Hypothesis

\section{Introduction}

Releases of volatile radionuclides, above all radiocesium, into the environment triggers concern for the environmental and human health as well as for food safety. Ingestion of contaminated food is the main pathway for internal exposure with anthropogenic radionuclides [1-4].

Georg Steinhauser

steinhauser@irs.uni-hannover.de

1 Institute of Radioecology and Radiation Protection, Leibniz Universität Hannover, Herrenhäuser Str. 2, 30419 Hannover, Germany

2 Clinical Department for Farm Animals and Herd Management, University of Veterinary Medicine Vienna, Veterinärplatz 1, 1210 Vienna, Austria
Wild boars (Sus scrofa) are well-known accumulators of radiocesium in their soft tissues [5-13]. This makes them a sensitive meat source, especially in contaminated areas in Europe and Japan, as a result of the Chernobyl and Fukushima nuclear accidents [14], respectively. They feed on cesium-rich fodder, including mushrooms, lichens, worms and snails, which explains why they exhibit higher ${ }^{137} \mathrm{Cs}$ activity concentrations in their tissues than grazing animals such as cattle. Nevertheless, the activity levels in their bodies seem not to correlate with the levels in their abiotic environment. It was often observed that the radiocesium levels in wild boars remain constant over longer periods of time or-even more puzzling — tend to increase over time, while the radiocesium levels in their abiotic environment (above all: soil) as well as in plants [15] and other animals decrease considerably over time $[6,9,11,13,16]$. Radiocesium levels in soil decrease with an effective half-life ( $\left.T_{\text {eff }}\right)$ that is typically shorter than the physical half-life $\left(T_{1 / 2}=30.08 y\right)$, because of the combination of physical ( $T_{\text {phys }}$ or $\left.T_{1 / 2}\right)$ and ecological half-life ( $\left.T_{\text {eco }}\right)$ (see Eq. 1).

$\frac{1}{T_{\text {eff }}}=\frac{1}{T_{\text {eco }}}+\frac{1}{T_{\text {phys }}}$

The ecological half-life takes into account losses due to washout, uptake by plants/animals/other biota etc. [17], and hence the effective half-life of radiocesium in soil may be as short as one third of the physical half-life [18]. Only on very few occasions, an increase of a radionuclide's concentration in the environment is deemed possible, such as in case of the deposition of resuspended materials [19-22]. Therefore the question arises, how wild boars remain a source of constant high or even increasing level of activity while the levels in their surrounding are ever decreasing. Several hypotheses were presented and discussed by the 
nuclear and veterinary medical communities. One argument that could be heard was that the overpopulation of wild boars induces food stress and forces them to dig out their food from deeper underground. However, such food stress usually does not occur within the European wild boar populations, and it would cause temporary infertility within the distressed communities. Such temporary infertility would exhibit a certain degree of self-regulation for the overpopulated communities. Other hypotheses focus on the wild boars' feed. It was often observed that mushrooms may exhibit a key role in the internal contamination levels of wild boars. Accordingly, the hypothesis says that it has taken years for radiocesium to migrate down to soil horizons where they can be taken up by fungi of the genus Elaphomyces with a variety of 25 truffle-like species. These fungi have been shown to be potent cesium accumulators [23], and it has been suggested that these fungi are responsible for the persistent radiocesium levels in wild boars [13, 24]. However, since the "Cs horizon" does not migrate linearly through the soil horizon, there are some questions how mushrooms can compensate the losses of Cs in their environment through radioactive decay as well as washout and migration processes.

In the present study, we investigated a different hypothesis for the peculiar phenomenon of constant radiocesium in boars: Could there be any reservoir within the wild boars' organism that supplies the muscle tissue, which is of entire interest for humans, with a constant level of radiocesium? As an alkali metal, the physiological behavior of the $\mathrm{Cs}^{+}$ion is generally associated with the behavior of essential $\mathrm{K}^{+}$. The monovalent alkali ions are only expected to accumulate in aqueous media. However, with its low charge density, could it be that $\mathrm{Cs}^{+}$may exhibit a more lipophilic characteristics inside the body than one might have anticipated? Would it be possible that radiocesium is hence accumulated preferentially in the wild boars' fat tissue and went unnoticed in the organ screenings that naturally focused primarily on muscle tissue (i.e., the human food source)? For example, in the extensive study by Tanoi et al., several organs and tissue types of wild boars were investigated for their contamination levels, however, no primary fat tissue has been objective in their study [5]. Fielutz even reported that fat was removed prior to the radiometric measurement of muscle tissue [13]. Literature did not provide further insight into the accumulation characteristics of radiocesium in fat tissue and hence warranted for a further investigation in this study.

\section{Materials and methods}

Four wild boars were used for this study. They were hunted down in Western Germany between February and April 2016 (Table 1).
Several samples of skeletal muscles and fat tissue were taken per wild boar. Additionally, no. 1 was sampled for tongue, brain, and omentum, no. 2 for brown adipose tissue, spinal marrow, tongue, and heart, no. 3 for spinal marrow, and tongue, and no. 4 for omentum, spinal marrow, heart, and tongue. The general idea behind sampling was covering all three types of interesting tissue types for the testing of the study's hypothesis: skeletal muscle tissue, specialized and/ or well-perfused muscle tissue/organs (heart and tongue), and various types of fat tissue or fat-enriched organs (white fat tissue, brown adipose tissue, greater omentum, as well as the central nervous system, i.e., brain or spinal marrow).

The tissue samples were weighed in fresh state into petri dishes of suitable diameter, sealed into air-tight polyethylene bags in order to minimize mass fluctuations due to the evaporation of moisture and deep frozen at $-18^{\circ} \mathrm{C}$ for storage. Gamma-ray spectrometry was conducted at a Canberra GR2818 $131 \mathrm{~cm}^{3}$ HPGe gamma detector with $28 \%$ relative efficiency at the IRS in Hannover. The deepfrozen samples were positioned on top of the gamma detector and measured for approximately $24 \mathrm{~h}$ each (or less, if a counting uncertainty of $<10 \%$ could be reached within a shorter time-span). The efficiency of each geometry was determined via a QCY48 multinuclide reference material with certified activities. Only the characteristic $662 \mathrm{keV}$ line of ${ }^{137} \mathrm{Cs}$ was used for the evaluation of the spectra. Uncertainties are mainly due to counting statistics in this setup.

\section{Results and discussion}

The results of the study are tabulated in Table 2. Activity levels in this study's wild boars were rather moderate compared with what has been reported in German wild boars previously $[6,13]$.

The data show that fat tissue does contain some radiocesium, however, not comparable to the contamination levels of skeletal muscle tissue. The $\left({ }^{137} \mathrm{Cs}\right.$ activity concentration in white fat tissue $) /\left({ }^{137} \mathrm{Cs}\right.$ activity concentration in skeletal muscle tissue) ratio ranges between 10 and $30 \%$. The same trend could be observed with other types of fat tissues, as shown in Fig. 1. This figure illustrates the ratio of activity in skeletal muscle tissue (tissue category A) versus fat tissue (tissue category C). It shows that activity concentrations in muscle tissue are generally higher than in fat tissues, with only one possible exception: spinal marrow in boar \#3. However, this outlier is not significant when the uncertainties of the gamma measurement are taken into account. All other samples exhibited a ratio of $\left({ }^{137} \mathrm{Cs}\right.$ activity concentration in fat tissue $) /\left({ }^{137} \mathrm{Cs}\right.$ activity concentration in skeletal muscle tissue) $<1$. Fat tissue hence is not a reservoir for radiocesium. Remarkably, however, 
Table 1 Wild boars included

\begin{tabular}{llllll}
\hline & Date of shooting & Approx. age & Mass $(\mathrm{kg})$ & Sex & Location \\
\hline Boar \#1 & 27.02 .2016 & 14 months & 42 & Female & Bad Dürkheim \\
Boar \#2 & 28.02 .2016 & 5 months & 28 & Male & Bad Dürkheim \\
Boar \#3 & 21.03 .2016 & 2-3 years & 44 & Female & Bad Dürkheim \\
Boar \#4 & 06.04 .2016 & 4 months & 23 & Male & Wendenberg \\
\hline
\end{tabular}

Table 2 Results of the gamma-spectrometric measurement in various tissue types in wild boars

\begin{tabular}{|c|c|c|c|c|}
\hline Boar no. & Tissue type & $\begin{array}{l}\text { Tissue } \\
\text { category }\end{array}$ & $\begin{array}{l}{ }^{137} \mathrm{Cs} \text { activity } \\
\text { concentration } \mathrm{Bq} / \mathrm{kg} \text { (f.w.) }\end{array}$ & $\begin{array}{l}\text { Uncertainty } \\
(\%)\end{array}$ \\
\hline 1 & Muscle tissue & A & 16 & 6.7 \\
\hline 1 & Tongue & B & 13 & 11 \\
\hline 1 & Brain & $\mathrm{C}$ & 8.5 & 6.5 \\
\hline 1 & Omentum & $\mathrm{C}$ & 7.9 & 9.0 \\
\hline 1 & White fat tissue & $\mathrm{C}$ & 1.6 & 43 \\
\hline 2 & Muscle tissue & A & 80 & 2.5 \\
\hline 2 & Heart & $\mathrm{B}$ & 47 & 3.3 \\
\hline 2 & Tongue & B & 59 & 2.5 \\
\hline 2 & Brown adipose tissue & $\mathrm{C}$ & 9.1 & 14 \\
\hline 2 & Spinal marrow & $\mathrm{C}$ & 38 & 23 \\
\hline 2 & White fat tissue & $\mathrm{C}$ & 16 & 7.5 \\
\hline 3 & Muscle tissue & A & 9.6 & 9.0 \\
\hline 3 & Tongue & B & 3.2 & 36 \\
\hline 3 & Spinal marrow & $\mathrm{C}$ & 12 & 20 \\
\hline 3 & White fat tissue & C & 2.2 & 30 \\
\hline 4 & Muscle tissue & A & 63 & 4.7 \\
\hline 4 & Heart & B & 38 & 9.9 \\
\hline 4 & Tongue & B & 40 & 5.0 \\
\hline 4 & Omentum & $\mathrm{C}$ & 10 & 9.1 \\
\hline 4 & Spinal marrow & $\mathrm{C}$ & 28 & 6.6 \\
\hline 4 & White fat tissue & $\mathrm{C}$ & 19 & 11 \\
\hline
\end{tabular}

$A$ skeletal muscle tissue, $B$ specialized muscle tissue, $C$ various types of fat tissue, $f . w$. fresh weight

${ }^{137} \mathrm{Cs}$ accumulated in the central nervous system (CNS) and thus links the CNS to the skeletal muscle tissue with respect to high radiocesium activity levels.

A second, interesting insight comes from the comparison of skeletal muscle tissue (tissue category A) versus specialized muscle tissue (tissue category B). Specialized muscle tissues, i.e. heart and tongue, seem to exhibit similar activities as skeletal muscle tissues, but always at a slightly lower degree, as shown in Fig. 2. This phenomenon has been reported previously by Tanoi et al. [5], who also observed a depletion of ${ }^{137} \mathrm{Cs}$ activity concentrations in tongue and heart tissue, respectively, compared with skeletal muscle tissue. One may argue that this may be a consequence of hunting, when most blood supply is driven to skeletal muscles. However, Tanoi et al. [5] already showed that blood itself is severely depleted in radiocesium, at least compared with skeletal muscle tissue.

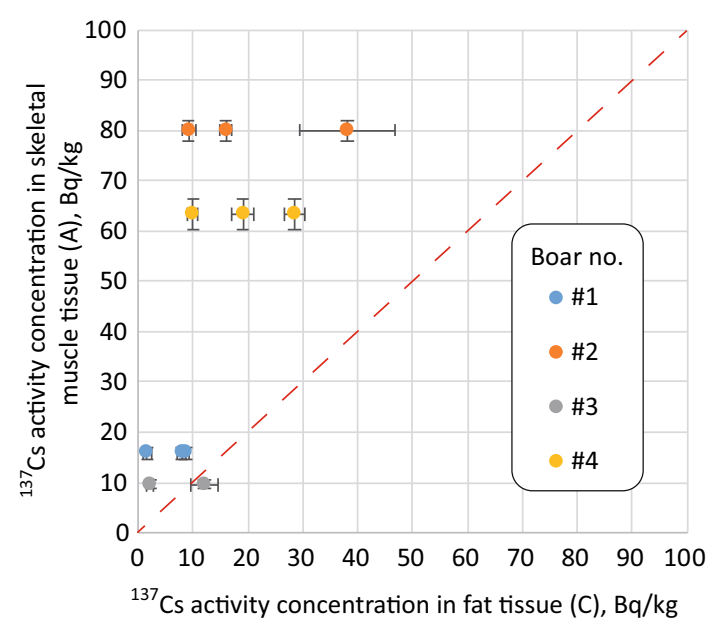

Fig. 1 Comparison of ${ }^{137} \mathrm{Cs}$ activity concentrations in fat tissue versus skeletal muscle tissue of the boars 


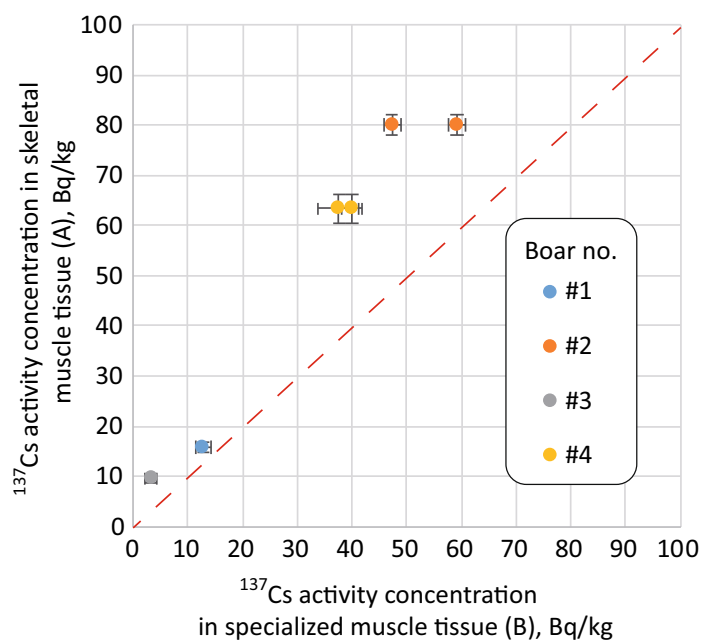

Fig. 2 Comparison of ${ }^{137} \mathrm{Cs}$ activity concentrations in specialized muscle tissue versus skeletal muscle tissue of the boars

Blood perfusion alone, hence cannot explain higher radiocesium levels in skeletal muscles. The ratios of activity concentrations in various tissue types compare quite well (but not exactly) between Tanoi et al. [5] and this study. The ratio of the ${ }^{137} \mathrm{Cs}$ distribution between brain/skeletal muscle was found to be about 0.25 (Tanoi et al.) but was slightly higher in animal no. 1 of this study with about 0.5 . However, there is decent agreement in the ratios of ${ }^{137} \mathrm{Cs}$ activity concentrations of heart/skeletal muscle tissue of approximately 0.53 (Tanoi et al.) and 0.59 (this study). The ratio of ${ }^{137} \mathrm{Cs}$ in tongue/skeletal muscle tissue was about 0.7 (Tanoi et al.) and ranged between 0.34 and 0.81 in this study.

Tanoi et al. [5] already showed that other types of tissue, such as bone or liver, only exhibit low or intermediate contamination levels. Our study, however, was the first that focused on various types of fat tissue that had not been in the focus of research so far.

Table 2 also shows that the two lighter male animals exhibited higher contamination levels than the heavier female animals. This is a rather unusual observation as the biological half-life tends to increase with increasing weight of the organism. It is very unlikely that such phenomenon is due to sex-specific differences, because such drastic differences do not usually occur in trace element distributions between male and female members of a mammal species. It is possible that the differences are due to differences in the specific diet of the animals, but also that the organisms of intensely growing individuals have a different trace element demand and hence a different radiocesium accumulation behavior. In any case, the number of animals investigated is not great enough to substantiate any hypotheses for this phenomenon by statistical means.

\section{Conclusions}

Although considerable radiocesium activities were found in various fat tissues of German wild boars, fat tissue does not act as a reservoir of ${ }^{137} \mathrm{Cs}$ for muscle tissue and other organs of the wild boar. Our study's working hypothesis, therefore, cannot explain the peculiar phenomenon of constant (or even increasing) radiocesium levels in wild boars' meat that have been observed for many years or even decades. Taken our results together, high (and constant) radiocesium levels in wild boars are more likely caused by contaminated feed uptake, as primarily well perfused tissues are affected. The main culprit for the anomalous behavior of ${ }^{137} \mathrm{Cs}$ in wild boars is probably an anomalous cesium accumulator within the wild boars' food chain (possibly a mushroom such as Elaphomyces). In agreement with present knowledge, wild boars apparently resorb radiocesium intestinally and spread it via the blood stream to the periphery, but, as our study shows, without forming depots in fatty compartments. One exception is the CNS that accumulates radiocesium to a higher degree than white fat tissue. Small molecules (and ions, including radionuclides) pass the blood-brain barrier, where these can accumulate. However, in Western countries, CNS tissues do not enter the human food chain and therefore this aspect may not be of further significance with respect to human health. Monitoring of muscle tissue for radiocesium will remain advisable in Europe (and possibly also Japan) for many years to come, as muscle tissue is the main accumulator of ${ }^{137} \mathrm{Cs}$.

Acknowledgements The authors would like to thank Prof. Alfred Moser for establishing the contact and initiating this collaboration.

\section{References}

1. Hamada N, Ogino H (2012) Food safety regulations: what we learned from the Fukushima nuclear accident. J Environ Radioact 111:83-99. doi:10.1016/j.jenvrad.2011.08.008

2. Merz S, Steinhauser G, Hamada N (2013) Anthropogenic radionuclides in Japanese food: environmental and legal implications. Environ Sci Technol 47(3):1248-1256. doi:10.1021/ es3037498

3. Hamada N, Ogino H, Fujimichi Y (2012) Safety regulations of food and water implemented in the first year following the Fukushima nuclear accident. J Radiat Res 53(5):641-671

4. Merz S, Shozugawa K, Steinhauser G (2015) Analysis of Japanese radionuclide monitoring data of food before and after the Fukushima nuclear accident. Environ Sci Technol 49:2875-2885. doi:10.1021/es5057648

5. Tanoi K, Uchida K, Doi C, Nihei N, Hirose A, Kobayashi NI, Sugita R, Nobori T, Nobori T, Nakanishi TM, Kanno M, Wakabayashi I, Ogawa M, Tao Y (2015) Investigation of radiocesium distribution in organs of wild boar grown in Iitate, Fukushima after the Fukushima Daiichi nuclear power plant accident. J Radioanal Nucl Chem. doi:10.1007/s10967-015-4233-Z 
6. Steinhauser G, Saey PRJ (2016) Cesium-137 in the meat of wild boars: a comparison of the impacts of Chernobyl and Fukushima. J Radioanal Nucl Chem 307:1801-1806. doi:10.1007/s10967015-4417-6

7. Gulakov AV (2014) Accumulation and distribution of ${ }^{137} \mathrm{Cs}$ and ${ }^{90} \mathrm{Sr}$ in the body of the wild boar (Sus scrofa) found on the territory with radioactive contamination. J Environ Radioact 127:171-175. doi:10.1016/j.jenvrad.2013.06.008

8. Sprem N, Babic I, Barisic D, Barisic D (2013) Concentration of ${ }^{137} \mathrm{Cs}$ and ${ }^{40} \mathrm{~K}$ in meat of omnivore and herbivore game species in mountain forest ecosystems of Gorski Kotar, Croatia. J Radioanal Nucl Chem 298(1):513-517. doi:10.1007/s10967-013-2475-1

9. Semizhon T, Putyrskaya V, Zibold G, Klemt E (2009) Timedependency of the ${ }^{137} \mathrm{Cs}$ contamination of wild boar from a region in Southern Germany in the years 1998 to 2008. J Environ Radioact 100(11):988-992. doi:10.1016/j.jenvrad.2009.06.023

10. Sontag G, Weinke HH, Scholz H (1989) Radioaktivität in Wildfleisch (Radioactivity of game meat). Ernährung/Nutrition 13(8/9):494-499 (in German)

11. Strebl F, Tataruch F (2007) Time trends (1986-2003) of radiocesium transfer to roe deer and wild boar in two Austrian forest regions. J Environ Radioact 98(1-2):137-152. doi:10.1016/j. jenvrad.2006.02.009

12. Vilic M, Barisic D, Kraljevic P, Lulic S (2005) ${ }^{137}$ Cs concentration in meat of wild boars (Sus scrofa) in Croatia a decade and half after the Chernobyl accident. J Environ Radioact 81(1):55-62. doi:10.1016/j.jenvrad.2004.12.001

13. Fielitz U (2004) Untersuchungen zum Verhalten von Radioäsium in Wildschweinen und anderen Biomedien des Waldes. Zwischenbericht IV zum Forschungsvorhaben StSch 4324 im Auftrag des Bundesministeriums für Umwelt, Naturschutz und Reaktorsicherheit (in German). www.environmental-studies.de/Zwi schenbericht_IV_-_FV_4324_2004.pdf. Accessed March 2017

14. Steinhauser G, Brandl A, Johnson TE (2014) Comparison of the Chernobyl and Fukushima nuclear accidents: a review of the environmental impacts. Sci Total Environ 470-471:800-817. doi:10.1016/j.scitotenv.2013.10.029

15. Merz S, Shozugawa K, Steinhauser G (2016) Effective and ecological half-lives of ${ }^{90} \mathrm{Sr}$ and ${ }^{137} \mathrm{Cs}$ observed in wheat and rice in Japan. J Radioanal Nucl Chem 307:1807-1810. doi:10.1007/ s10967-015-4352-6

16. Calmon P, Thiry Y, Zibold G, Rantavaara A, Fesenko S (2009) Transfer parameter values in temperate forest ecosystems: a review. J Environ Radioact 100(9):757-766. doi:10.1016/j.jenv rad.2008.11.005

17. Pröhl G, Ehlken S, Fiedler I, Kirchner G, Klemt E, Zibold G (2006) Ecological half-lives of ${ }^{90} \mathrm{Sr}$ and ${ }^{137} \mathrm{Cs}$ in terrestrial and aquatic ecosystems. J Environ Radioact 91:41-72. doi:10.1016/j. jenvrad.2006.08.004

18. Steinhauser G, Merz S, Hainz D, Sterba JH (2013) Artificial radioactivity in environmental media (air, rainwater, soil, vegetation) in Austria after the Fukushima nuclear accident. Environ Sci Pollut Res 20(4):2527-2537. doi:10.1007/s11356-012-1140-5

19. Hirose K (2013) Temporal variation of monthly ${ }^{137}$ Cs deposition observed in Japan: effects of the Fukushima Daiichi nuclear power plant accident. Appl Radiat Isot 81:325-329. doi:10.1016/ j.apradiso.2013.03.076

20. Hirose K (2015) Two-years trend of monthly ${ }^{137}$ Cs deposition observed in Kanto and south Tohoku areas, Japan: effects of the Fukushima Dai-ichi nuclear power plant accident. J Radioanal Nucl Chem 303:1327-1329

21. Steinhauser G, Niisoe T, Harada KH, Shozugawa K, Schneider S, Synal H-A, Walther C, Christl M, Nanba K, Ishikawa H, Koizumi A (2015) Post-accident sporadic releases of airborne radionuclides from the Fukushima Daiichi nuclear power plant site. Environ Sci Technol 49(24):14028-14035. doi:10.1021/acs.est. $5 \mathrm{~b} 03155$

22. Akimoto K (2017) Temporal variations of air dose rates in east Fukushima during Japanese fiscal years 2012 and 2013. Health Phys 112(1):42-55

23. Horovitz CT, Schock HH, Horovitz-Kisimova LA (1974) The content of scandium, thorium, silver, and other trace elements in different plant species. Plant Soil 40(2):397-403. doi:10.1007/ BF00011522

24. Dvořák $P$, Snášel $P$, Beňová K (2010) Transfer of radiocesium in wild boar meat. Acta Vet Brno 79:85-91. doi:10.2754/ avb201079S9S085 